\title{
Cost minimization of supplying biomass for ethanol biorefineries
}

\section{Yayuan Jin *}

\section{Prabodh Illukpitiya**}

\begin{tabular}{|l|l|}
\hline$* *$ Corresponding Author & $*$ Graduate Assistant \\
Assistant Professor & Department of Agricultural and \\
Department of Agricultural and & Environmental Sciences \\
Environmental Sciences & Tennessee State University \\
Tennessee State University & Email: yjin@my.tnstate.edu \\
3500 John A. Merritt Blvd & \\
Nashville Tennessee 37209 & \\
USA. & \\
Phone: (615) 963-1877 & \\
Email: pillukpi@tnstate.edu & \\
& \\
\hline
\end{tabular}




\begin{abstract}
A major hurdle facing commercial biofuel production is the cost of producing the feedstock. Since biofuel feedstock is bulky in nature, a large proportion of cost needed to be allocated for harvesting and transportation of feedstock. Economic viability of ethanol production from cellulosic feedstock depends in part of the cost to produce, harvest and deliver feedstock to the ethanol production facilities. A well-developed harvesting and transportation system does not exist for most feedstock. Hence to determine accurate estimation of the harvest, transportation and storage costs is important in ethanol production. The objectives of the study are to determine the optimal harvesting unit for ethanol biorefinery and estimate harvesting, storage and transportation costs of switchgrass under various harvesting schedules. A biorefinery with the annual capacity of processing 4.16 million gallons of ethanol was considered. Based on average dry matter yield, total production area needed for annual harvesting was estimated. The harvesting units needed for the continuous harvest and supply of biomass were estimated based on information on the capacity of machineries etc. Accordingly various costs associated with operating and maintaining harvesting unit were estimated. Transportation units needed were estimated for continuous supply of feedstock to the refinery and the associated costs were calculated.
\end{abstract}

The number of machinery needed for a harvesting unit for the 90 day harvesting schedule are the most while year round harvesting schedules needs lesser number of machinery for a harvesting unit. Harvesting switchgrass in 90 day schedule is the most expensive scenario with all harvesting, hauling and storage costs added together. Year round harvesting schedule occurs as the least costly scenario. Sensitivity analysis shows 
the positive trend for harvesting and hauling costs to biomass yield, ethanol conversion technology and distance and decreasing trend for the range of truck speed considered. The results generated in this study will be useful designing optimal harvest of biomass for ethanol biorefinery.

Key words. energy; biorefinery; cost modelling; ethanol, harvest unit; sensitivity analysis 


\section{Introduction}

Energy is the most important factor of production in economy around the globe, and $90 \%$ of energy being produced commercially, comes from the non-renewable sources [1]. The growing concern with rising oil prices and global warming and its consequences are the immediate justification for reducing dependence on fossil fuels [2]. Also, predicted shortage of fossil fuel in future has encouraged researchers to look in to alternatives of petroleum derivatives [3]. Currently the USA consumes 19 million barrels of petroleum per day [4], and $70 \%$ of these are used for transportation. Thus, research on an alternative for transportation fuel has become significant. Over $60 \%$ of the 19 million barrels of crude oil consumed in USA per day is imported [5]. Due to instable international relationships with oil producing countries, it is crucial to discover alternate energy sources for future energy security. On the other hand, burning fossil fuels leads to concentrations of pollutants in water and air. It is the largest contributor of greenhouse gas emissions. This also is a justification for the need for alternate energy sources.

In recent past, many candidates for fossil fuel alternatives have been found and carefully evaluated [6]. Ethanol based biofuels produced from bioenergy feedstock is one notable alternative. Large amount of feedstock can be used to produce ethanol. Accordingly, those are classified as first and second generation feedstock. In the first generation, ethanol is produced mainly from sugar and starch biomass. Lignocellulosic biomass represents the second generation feedstock [7].

To reduce the dependency on petroleum, the U.S. government has imposed a series of regulations and policies to support biofuel production. For example, the United 
States Congress passed the Energy Independence and Security Act of 2007. This act mandates a minimum of 36 billion gallons of renewable fuel production annually by 2022 [8]. Following this act, a Renewable Identification Number (RIN) system was developed and executed by the U.S. Environmental Protection Agency (EPA) in 2010 to ensure compliance with this act [9]. The Billion Ton Report proposed that $30 \%$ of liquid transportation fuel be produced from renewable resources by 2030 [10]. To meet these goals, ethanol produced from corn kernels will not be sufficient hence wide range of suitable ethanol feedstock for various geographic regions.

\section{Problem Statement}

Meanwhile, several concerns have been raised regarding the production of first generation biofuels. One major concern centers on the issue of higher food prices due to competition with food crops. As the commodity prices have increased significantly since 2006, and the increasing demand by the biofuel sector for feedstock has been proved as the main contributor [11]. Other concerns on first generation biofuels also exist, such as only providing limited greenhouse gas (GHG) reduction benefits. Many of the problems associated with first generation biofuels can be addressed by shifting to second generation biofuels, where the lignocellulosic feedstock is to be produced from specialist energy crops grown on arable land [7].

Switchgrass, a perennial warm-season grass native to the USA, is widely recognized as a primary lignocellulose feedstock based on its high biomass content, strong adaptability to various soil conditions, and its beneficial nature to the environment [12]. In the whole process of producing switchgrass to ethanol, harvesting and hauling cost counts for a large portion among all the expense categories. In general, biorefinery 
can be classified into three classes based on capacity namely, large, medium and small scales. According to the economy of scale, the production costs associated with these different levels of biorefinery are different. Researchers have evaluated various aspects of harvesting, hauling and storage cost, but have mostly focused on large and medium scales. Harvesting and hauling costs for supplying feedstock for small-scale ethanol biorefineries is rarely mentioned. The main objective of this study is to analyze the effect of timing on switchgrass harvesting and hauling cost for ethanol biorefineries. The paper present various scenarios and factors to be considered in designing harvest and hauling cost model for ethanol biorefinery; identify harvesting units needed and analyze the harvesting costs under different time schedules and also determine the hauling unit needed for efficient transportation of feedstock and analyze costs. 


\section{Methodology and Data Sources}

Biomass production from switchgrass is considered for the harvesting and hauling cost model. Figure 1 shows the flow of feedstock from fields to biorefinery [13]. The annual feedstock requirement depends on the capacity of ethanol plant. The focus for this study is on a biorefinery with the capacity around 5 million gallons/ year).

Figure 1 here

Biomass harvesting unit consists of mowers, rakes, balers, field transporters, 150 $\mathrm{hp}$ tractors that can pull balers and $95 \mathrm{hp}$ tractors that can pull mowers and rakes. Harvesting unit needed also depends on harvesting schedule. Accordingly, yearly harvesting, 3 months and 6 months harvesting schedules were considered in the model. According to literature, a mower can harvest around $1.3 \mathrm{ha} / \mathrm{hr}$, which is $10.4 \mathrm{ha} / \mathrm{day}$, assuming 8 working hours per day [13]. The average capacity of baler is 1.0 ha/day, and of rake is 1.7 ha/day. Regarding to different scenarios, different harvest units were determined.

\subsection{Hauling cost}

There are different options for transporting harvested biomass to biorefinery. Biomass can be directly transported to the processing site using direct wagon pulled by tractors. If sufficient hauling units are not available, on farm storage facility is needed to store harvested biomass. For the year round harvesting schedule, three satellite storage locations are considered in the model. For a 40 kilometer radius, the satellite storages are located at 13, 32 and $40 \mathrm{~km}$ radius. Storage in biorefinery plants are considered available for 3 months and 6 months harvesting schedule since storage on site is considered more 
convenient and less costly expense due to large quantity of biomass. The storage site is assumed to have lifetime of 30 years.

The next option is to transfer the biomass to storage facility using transfer wagon, which is a semi-trailer. The average capacity of a semi-trailer is $18 \mathrm{MT}$. The biomass will be loaded into truck tailors using transloader and then transport to the processing site. The estimated times for loading and unloading a truck are 30 and 20 minutes respectively [14].

Several assumptions were made in estimating harvesting and hauling costs. For example, average annual per hectare biomass yield of switchgrass was taken as an average value of 15.7 MT.ha. This is accordance with considering the yield from various studies. For example [15] evaluated the yield per year and identified $30 \%$ yields $(4.48$ MT/ha) of the full yield potential production in the first year of production. In the second year, yields were $70 \%$ (11.21 MT/ha) of full yield potential. By the third year, yields were $100 \%$ (15.69 MT/ha). The study identified that it was more reasonable to expect

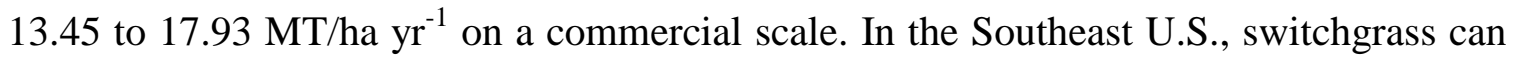
yield 15.69 to $35.87 \mathrm{MT} / \mathrm{ha}$; in the western Corn Belt, it can yield 11.21 to $13.45 \mathrm{MT} / \mathrm{ha}$ and 2.24 to 8.97 MT/ha in North Dakota [16].

\section{Table 1 here}

The ethanol conversion rate is an important determinant for study of this nature since quantity of biomass required for biorefineary varies with conversion rate. We used ethanol conversion rate as $82.6 \mathrm{gal} / \mathrm{Mt}$ based on recent evidences from literature. for example, using the Biomass Feedstock Composition and Property Database and the Theoretical Ethanol Yield Calculator, the theoretical ethanol yield for switchgrass is 
estimated to range from 88.7 to 101.5 gallons/MT with an average theoretical ethanol yield of 96.38 gallons/MT $[17,18]$. This is conducted from a study on 21 whole plant switchgrass samples. However, ethanol yields are limited to 50-80 percent of the theoretical potential [19]. In another study [20] the conversion rate of 69.76 gallons/MT was used to calculate Lignocellulosic Biomass (LCB) needs for switchgrass [20].

Table 2 here

The queuing time in the field for transfer and direct wagon was assumed to be 8 minutes. Distance from transfer site to the processing site was assumed as $40 \mathrm{kms}$. Details of machine specifications like horsepower, initial costs, age, salvage value factor, fuel and lubrication factors etc. were gathered from published data $[21,22,23]$.

The harvesting and hauling cost model was based on the economic engineering approach [22]. Accordingly, following formulas were used in cost estimation.

The total cost equals to sum of harvesting, hauling and storage cost, hence the cost function can be synthesized as follows:

$T C_{i}=H C_{i}+T P C_{i}+S C_{i}$

$T C_{i}=$ Total Cost

$H C_{i}=$ Harvesting Cost

$\mathrm{TPC}_{i}=$ Transportation Cost

$S C_{i}=$ Storage Cost

Switchgrass harvesting cost is a function of total ownership cost of machinery (TOC), fuel cost (Fuel), lubrication cost (Lubri) and repair cost (Repair). Labor cost will be calculated separately.

$H C_{i}=$ TOC $_{i}+$ Fuel $_{i}+$ Lubri $_{i}+$ Repair $_{i}$

TOC $_{i}=$ Total ownership cost $=$ capital recovery $+T I H$

Capital recovery $=($ total depreciation $*$ capital recovery factor $)+($ salvage value $*$ interest rate)

$\mathrm{TIH}=$ Taxes, insurance $\&$ Housing $=0.01 *$ purchase price

Fueli $=$ Fuel consumption 
Average gasoline consumption per hour $=0.060 *$ maximum PTO horsepower Average diesel consumption per hour $=0.044 *$ maximum PTO horsepower Lubri $_{i}=$ Lubrication Cost $=0.15 *$ Average cost for gasoline consumption

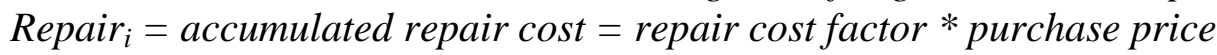

The cost of the transportation of biomass is similar to harvesting cost except for the type of machineries, thus the similar formula will be adopted. Accordingly, transportation cost function can be given as:

$T P C_{i}=$ TOC $_{i}+$ Fuel $_{i}+$ Lubri $_{i}+$ Repair $_{i}$

Total labor cost equals to labor cost in harvesting process and labor cost in hauling.

Labor $_{i}=$ labor cost for the harvest unit + labor cost for transportation

Given the variation in harvest days, the effect of harvesting schedule on total costs was identified. Following criteria were used to evaluate cost effectiveness under different scenarios. a). investment costs for harvesting and hauling unit; b). annual operating costs c). cost/l of ethanol; d). cost/MT of biomass; e). cost/ha. A sensitivity analysis was followed to identify how the key assumptions would affect the costs results. Price of diesel price, biomass yield, ethanol conversion rate and truck speed were the changing variables considered here. Finally profit margin/ton of biomass for different operations were analyzed.

\section{Results and Discussion}

The estimated harvesting costs for different harvesting schedules are shown in Table 3. Different combinations of harvest units (numbers of mowers, rakes, balers, 95 hp tractors, $155 \mathrm{hp}$ tractors and transporter stackers) are presented for 90, 180 and 300 day harvesting schedules respectively. Total ownership cost, repair cost, fuel cost and lubrication costs are calculated using the formulas provided above. Among these three 
schedules considered in this analysis, total ownership cost for 90 day harvesting schedule counts the most $(\$ 147,234)$ due to number of machines needed per harvest unit. Total annual ownership cost for 180 and 300 day schedules are $\$ 84,002$ and $\$ 56,021$ respectively. Total repair cost follows the same pattern that 90 day schedule costs most $(\$ 306,996)$ while the year round schedule costs the least $(\$ 119,733)$. Total fuel costs and lubrication costs are the same for three schedules due to the same working hours in the field ( $\$ 27,806$ for fuel and $\$ 40,621$ for lubrication cost). To summarize all these four categories of costs, 90 day harvesting schedule accounts highest cost $(\$ 765,657)$ compared to shorter harvesting schedules $(\$ 569,019$ and $\$ 487,181$ for 180 and 300 day schedules respectively).

\section{Table 3 here}

Table 4 shows the estimated transportation cost for three different harvesting schedules. The hauling process for year round harvesting schedule is different from shorter schedules. It is assumed that three satellite storage facilities are located at 13,32 and $40 \mathrm{kms}$ radius as temporary storage sites (the ownership of these sites was not accounted in this analysis). The three month harvesting schedule, which is the most intensive schedule compared to other scenarios, requires the most hauling machines ( 8 trucks). Accordingly, the ownership and repair costs were highest $\$ \$ 17,920$ and $\$ 75,200$ for ownership and repair respectively). The costs for ownership and repair for these three schedules in hauling process have the same rank order as the harvesting process. The fuel cost $(\$ 68,654)$ and lubrication cost $(\$ 10,298)$ are quite the same between 90 and 180 day harvesting schedule due to same transportation distance and working hours. The total 
hauling cost of 3 months harvesting is the most expensive $(\$ 172,072)$ while year round harvesting counts the least $(\$ 85,450)$.

Table 4 here

Total labor costs including in field loading operation and transportation were calculated based on 8 hour daily working schedule. The total labor costs in both 90 and 180 day harvesting schedules are identified as the same costly schedule $(\$ 208,354)$ due to same working hours while year round schedule counts the least $(\$ 185,391)$. See table Table 5 for details.

Table 5 here

Since year round harvesting schedule is based on temporary satellite storage locations, there is no storage needed at the biorefinery site. For 90 and 180 day harvesting schedules, storage-building costs were calculated. The switchgrass harvested in 90 days requires larger space to store hence require substantial costs for building (Table 6). Accordingly, 90 day harvesting schedule account higher storage costs $(\$ 105,064)$ compared to 180 day schedule $(\$ 60,037)$.

Table 6 here

Table 7 shows the total estimated costs for harvesting, hauling, labor and storage.. Accordingly the most expensive cost occurs under 90 day schedule $(\$ 1,251,147)$ while 180 day harvesting schedule counts the second and year round schedule the last (\$962,922 and \$758,022 respectively).

Table 7 here

\subsection{Sensitivity Analysis}


Estimated costs of harvesting and hauling switchgrass is sensitive to the variables such as price of diesel, biomass yield, ethanol conversion ratios, operating speed of the truck etc (see figure 2). This uncertainty factors were accounted in the analysis. In the event of increasing the price of diesel, there is an increasing trend for harvesting costs. For example, if the price of diesel increases from $\$ 2.85$ to $\$ 3.80$, harvesting costs/ha would increase by $\$ 36, \$ 35$ and $\$ 33$ for quarterly, semiannual and annual harvesting scenarios.

Figure 2 here

If switchgrass yield improvement due to plant breeding efforts in future, the harvesting costs per hectare would increases in all three scenarios. For example, when per hectare switchgrass yield increases from 11.2 to $22.4 \mathrm{MT} / \mathrm{yr}$, total cost/ha would increases by $\$ 101, \$ 90$ and $\$ 48$ for 90,180 day and annual schedules respectively.

Conversion ratios stand for the technology level adopted by biorefinery. As the conversion ratio increases, costs on a per hectare basis increase. Disregarding some sudden drop points, they perform slightly increasing trends overall. For example, when conversion rate changes from 317 to $459 \mathrm{l} / \mathrm{MT}$, total cost per hectare increases by $\$ 15$, $\$ 17$ and $\$ 20$ for 90,180 and 300 day harvesting schedules respectively.

The changes of truck speed bring little impact on the cost per hectare. As the speed increases, a slight decline of cost is anticipated. If truck speed increases from 56 to 89 $\mathrm{km} / \mathrm{hr}$, total cost $/ \mathrm{ha}$ decreases by $\$ 8, \$ 9$ and $\$ 5$ for 90,180 and 300 day harvesting schedules respectively.

\subsection{Profit Margin}


Based on the estimated costs for harvesting and hauling switchgrass, the estimated profit margin for custom harvesting and operation is presented in Table 8 . The custom rate for harvesting was estimated as $\$ 33.47$. Subtracting total costs for three scenarios the profit margin ranges from $\$ 17.85$ - $\$ 22.86 / \mathrm{MT}$ of biomass. For hauling operations, the custom rate was estimated as $\$ 10.06$, hence the profit margins ranges from $\$ 5.04-\$ 6.22 /$ ton. Thus, the total profit margins were between $\$ 22.89$ - $\$ 29.08 / \mathrm{MT}$ of biomass.

Table 8 here

\section{Conclusions}

A biorefinery with the annual capacity of processing 4.16 million gallons of ethanol was considered in this research. Based on average dry matter yield, total production area of switchgrass needed for annual harvesting was 3,214.5ha. The harvesting units needed for the continuous harvest and supply of biomass were estimated based on information on the capacity of machineries etc. Accordingly various costs associated with operating and maintaining harvesting unit were estimated. Transportation units needed were estimated for continuous supply of feedstock to the refinery and the associated costs were calculated. Most number of machineries required for a harvesting unit for 90 day schedule while year round harvesting operations need least number of machinery for a harvesting unit. Given this fact, harvesting in shorter schedules are comparatively more expensive compared to longer schedules. Accounting harvesting, hauling and storage costs together, 300 day harvesting schedule occurs as the least costly scenario. The results generated from this study will be useful for supply chain development for supply of biomass for ethanol biorefineries. The ethanol biorefineries can evaluate options for maintaining own harvesting unit for their field operations or consider custom harvesting 
for biomass supply. The results will be useful for harvesting companies to determine initial capital investment, annual operation costs and determine production costs based on timing of operations. The information will also be useful to estimate profit margin for businesses.

\section{Acknowledgement}

The authors wish to acknowledge USDA-NIFA for providing funding for this project

\section{References}

[1] Birur, D.K., T.W. Hertel, and W.E. Tyner. Impact of biofuel production on world agricultural markets: A computable general equilibrium analysis. GTAP working paper no. 53 2008. Available [online]:

https://www.gtap.agecon.purdue.edu/resources/download/4034.pdf?origin=publicatio n_detail

[2] WWI. Biofuels for transportation. Global potential and implications for sustainable agriculture and energy in the $21^{\text {st }}$ century. Extended summary. A report prepared by the World Watch Institute for the German Federal Ministry of Food, Agriculture and Consumer Protection 2006.

[3] Pimental, D. and Patzek, T.W. Ethanol production using corn, switchgrass, and wood; biodiesel production using Soybean and Sunflower. Natural Resources Research 2005; 14(1): 65-76.

[3] Energy Information Administration (EIA). How much oil is consumed in the United States? 2013. Available [online] http://www.eia.gov/tools/faqs/faq.cfm?id=33\&t=6

[4] Morse, E.L. Lee, EG., Ahn, DP., Doshi, A., Kleinman, SM and Yuen, A. Energy 2020: North America, the New Middle East?, Citi GPS: Global Perspectives \& Solutions, March 20, 2012.

[5] National Renewable Energy Laboratory (NREL). Renewable energy: an overview. Energy Efficiency and Renewable Energy, DOE/GO-102001-1102, FS175. 2001. Available [online] http://www.nrel.gov/docs/fy01 osti/27955.pdf

[6] Sims, R., Taylor M., Saddler, J. and Mabee W. From $1^{\text {st }}-$ to $2^{\text {nd }}$-generation biofuel technologies." International Energy Agency. 2008. Available [online] https://www.iea.org/publications/freepublications/publication/2nd_Biofuel_Gen.pdf 
[7] Energy Independence and Security Act. Summary of Provisions. 2007. Available [online]

http://www.eia.gov/oiaf/aeo/otheranalysis/aeo_2008analysispapers/eisa.html

[8] Mcphail, L., Westcott, P. and Lutman, H. The Renewable Identification Number System and U.S. biofuel mandates. 2011. Available [online] http://www.ers.usda.gov/media/138383/bio03.pdf

[9] U.S. Department of Energy. U.S. Billion-Ton Update: Biomass Supply for a Bioenergy and Bioproducts Industry. R.D. Perlack and B.J. Stokes (Leads), ORNL/TM-2011/224. Oak Ridge National Laboratory, Oak Ridge, TN. 227p. August 2011.

[10] Westhoff, PC. The economics of food: how feeding and fueling the planet affects food prices. FT Press, Upper Saddle River, New Jersey. 2010.

[11] Rinehart, L. Switchgrass as a bioenergy crop. National Center for Appropriate Technology. 2006. Available at: http://attra.ncat.org/attra-pub/PDF /switchgrass.pdf

[12] Hwang, S. Days available for harvesting switchgrass and the cost to deliver switchgrass to a biorefinery. PhD dissertation, Oklahoma State University. 2007. Available [online] http://digital.library.okstate.edu/etd/umi-okstate-2429.pdf

[13] Duffy, M. Estimated costs for production, storage and transportation of switchgrass. Ag Decision Maker, A1-22. Iowa State University. 2008.

[14] Garland, CD. Growing and harvesting switchgrass for ethanol production in Tennessee. University of Tennessee Cooperative Extension Service, SP701-A. 2008. Available [online] https://utextension.tennessee.edu/publications/Documents/SP701-A.pdf

[15] Comis, D. Switching to switchgrass makes sense. Agricultural Research, USDAARS. 2006. Available [online]: http://www.ars.usda.gov/is/AR/archive/jul06/grass0706.pdf

[16] US Department of Energy (DOE). Theoretical ethanol yield calculator. 2010 Available [online] www.eere.energy.gov/biomass/ethanol_yield_calculator.html

[17] US Department of Energy (DOE).. Biomass feedstock composition and property database. $2010^{\mathrm{b}}$. Available [online] www.afdc.energy.gov/biomass/progs/search2.chi?19561

[18] Mclaughlin, S.B. and Kszos, L.A. Development of switchgrass (Panicum Virgatum) as a bioenergy feedstock in the United States. Biomass and Bioenergy 2005; 28:515-35. 
[19] Wang, M., Saricks, C. and Santini, D. Effects of fuel use on fuel-cycle energy and greenhouse emissions. ANL/ESD-38, Center for Transportation Research. Energy Systems Division, Argonne National Laboratory, Argonne, IL. 1999.

[20] Lazarus W. Machinery cost estimates. University of Minnesota Extension Service. 2009. Available [online]: http://www.apec. umn.edu/faculty/wlazarus/documents/mf2009.pdf.

[21] Edwards, W. Estimating Farm Machinery Costs, Ag Decision Maker File A3-29, Iowa State University Extension Publication PM-710, November 2009. Available [online] http://www.extension.iastate.edu/agdm/cdmachinery.html 
Table 1. Potential yield of switchgrass.

\begin{tabular}{|l|l|r|}
\hline Source & \multicolumn{1}{|c|}{ Year } & \multicolumn{1}{c|}{ Yield (MT/ha) } \\
\hline Kszos et al. & 2002 & 13.41 \\
\hline Perrin et al. & 2003 & $5.60-6.73$ \\
\hline Rinehart & 2006 & $2.24-35.87$ \\
\hline Tiffany et al. & 2006 & 8.97 \\
\hline Busby et al. & 2007 & 32.42 \\
\hline Duffy & 2008 & 8.97 \\
\hline
\end{tabular}

Table 2. Various ethanol conversion rates.

\begin{tabular}{|l|l|r|}
\hline Source & Year & Conversion Rate (gallons/MT) $^{1}$ \\
\hline Mclaughlin et al. & 1999 & $88.7-101.5$ \\
\hline Wang et al. & 1999 & 69.8 \\
\hline Thorsell et al. & 2004 & 68.8 \\
\hline Comis,D. & 2006 & 88.1 \\
\hline Schmer et al. & 2008 & 83.5 \\
\hline Haque and Epplin & 2010 & 91.8 \\
\hline
\end{tabular}

Note: ${ }^{1}$ Gallons refer to imperial gallons (4.55l) 
Table 3. Estimated yearly harvesting costs under different harvesting schedules.

\begin{tabular}{|c|c|c|c|}
\hline \multirow[t]{2}{*}{ Category } & \multicolumn{3}{|c|}{ Harvesting Schedule } \\
\hline & 3 months & 6 months & Year round \\
\hline Mowers (no.) & 4 & 2 & 1 \\
\hline Rakes (no.) & 3 & 2 & 1 \\
\hline Balers (no.) & 5 & 3 & 2 \\
\hline 95hp tractors (no.) & 7 & 4 & 2 \\
\hline 155hp tractors (no.) & 5 & 3 & 2 \\
\hline Transporter stacker (no.) & 2 & 1 & 1 \\
\hline Capital recovery factor & 0.13 & 0.13 & 0.13 \\
\hline Interest rate & $5 \%$ & $5 \%$ & $5 \%$ \\
\hline Total ownership costs & $\$ 147,234$ & $\$ 84,002$ & $\$ 56,021$ \\
\hline Total repair cost & $\$ 306,996$ & $\$ 173,590$ & $\$ 119,733$ \\
\hline Diesel consumption factor & 0.044 & 0.044 & 0.044 \\
\hline Diesel cost/liter & $\$ 0.86$ & $\$ 0.86$ & $\$ 0.86$ \\
\hline Total diesel fuel cost & $\$ 270,806$ & $\$ 270,806$ & $\$ 270,806$ \\
\hline Total lubrication cost & $\$ 40,621$ & $\$ 40,621$ & $\$ 40,621$ \\
\hline Total harvesting cost & $\$ 765,657$ & $\$ 569,019$ & $\$ 487,181$ \\
\hline Cost/liter & $\$ 0.04$ & $\$ 0.03$ & $\$ 0.026$ \\
\hline Cost/MT & $\$ 15.19$ & $\$ 11.29$ & $\$ 9.67$ \\
\hline Cost/hectare & $\$ 238.38$ & $\$ 177.17$ & $\$ 151.67$ \\
\hline
\end{tabular}

Table 4. Estimated yearly hauling cost for different harvesting schedules.

\begin{tabular}{|l|r|r|r|}
\hline \multirow{2}{*}{ Category } & \multicolumn{3}{|c|}{ Harvesting Schedule } \\
\cline { 2 - 4 } & \multicolumn{1}{|c|}{ 3 months } & 6 months & \multicolumn{1}{|c|}{ Year round } \\
\hline Number of trucks & 8 & 4 & 3 \\
\hline Initial cost per truck & $\$ 20,000$ & $\$ 20,000$ & $\$ 20,000$ \\
\hline Total Ownership costs & $\$ 17,920$ & $\$ 8,960$ & $\$ 6,720$ \\
\hline Total repair cost & $\$ 75,200$ & $\$ 37,600$ & $\$ 28,200$ \\
\hline Total diesel cost & $\$ 68,654$ & $\$ 68,654$ & $\$ 43,939$ \\
\hline Total lubrication cost & $\$ 10,298$ & $\$ 10,298$ & $\$ 6,591$ \\
\hline Total hauling cost & $\mathbf{\$ 1 7 2 , 0 7 2}$ & $\mathbf{\$ 1 2 5 , 5 1 2}$ & $\mathbf{\$ 8 5 , 4 5 0}$ \\
\hline Cost/litre & $\$ 0.009$ & $\$ 0.007$ & $\$ 0.004$ \\
\hline Cost/MT & $\$ 3.42$ & $\$ 2.49$ & $\$ 1.70$ \\
\hline Cost/hectare & $\$ 53.57$ & $\$ 39.07$ & $\$ 26.61$ \\
\hline
\end{tabular}

Table 5. Estimated yearly labor cost for different harvesting schedules. 


\begin{tabular}{|c|c|c|c|}
\hline \multirow[t]{2}{*}{ Category } & \multicolumn{3}{|c|}{ Harvesting Schedule } \\
\hline & 3 months & 6 months & Year round \\
\hline \multicolumn{4}{|l|}{ Labor Wage per hour } \\
\hline Truck driver & $\$ 18.37$ & $\$ 18.37$ & $\$ 18.37$ \\
\hline Labor on field & $\$ 12$ & $\$ 12$ & $\$ 12$ \\
\hline Total labor cost (trucks) & $\$ 106,308$ & $\$ 106,308$ & $\$ 83,345$ \\
\hline Total labor cost (field) & $\$ 102,046$ & $\$ 102,046$ & $\$ 102,046$ \\
\hline Total labor cost & $\$ 208,354$ & $\$ 208,354$ & $\$ 185,391$ \\
\hline Cost/liter & $\$ 0.01$ & $\$ 0.01$ & $\$ 0.01$ \\
\hline Cost/MT & $\$ 4.13$ & $\$ 4.13$ & $\$ 3.68$ \\
\hline Cost/hectare & $\$ 64.87$ & $\$ 64.87$ & $\$ 57.72$ \\
\hline
\end{tabular}

Table 6. Estimated yearly storage cost for different harvest schedules.

\begin{tabular}{|l|r|r|}
\hline \multirow{2}{*}{ Category } & \multicolumn{2}{|c|}{ Harvesting Schedule } \\
\cline { 2 - 3 } & \multicolumn{1}{|c|}{ 3 months } & \multicolumn{1}{c|}{ 6 months } \\
\hline Biomas requirement (MT/day) & 167.8 & 167.8 \\
\hline Harvest biomass (MT/day) & 559.73 & 280.32 \\
\hline Maximum storage (MT) & 35,280 & 20,159 \\
\hline $\begin{array}{l}\text { Factor to determine size of storage } \\
\text { (sq.meters/MT) }\end{array}$ & 1.19 & 1.19 \\
\hline Storage dimensions (sq.meter) & 41,832 & 23,904 \\
\hline $\begin{array}{l}\text { Cost per square meter for finished } \\
\text { building }\end{array}$ & $\$ 75.35$ & $\$ 75.35$ \\
\hline Building cost & $\$ 3,151,936$ & $\$ 1,801,106$ \\
\hline Building cost/year & $\mathbf{\$ 1 0 5 , 0 6 4}$ & $\mathbf{\$ 6 0 , 0 3 7}$ \\
\hline Cost/liter & $\$ 0.005$ & $\$ 0.003$ \\
\hline Cost/MT & $\$ 2.08$ & $\$ 1.19$ \\
\hline Cost/hectare & $\$ 32.72$ & $\$ 18.68$ \\
\hline
\end{tabular}

Table 7. Total harvesting and hauling costs for switchgrass.

\begin{tabular}{|l|r|r|r|}
\hline \multirow{2}{*}{ Category } & \multicolumn{3}{|c|}{ Harvesting Schedule } \\
\cline { 2 - 4 } & \multicolumn{1}{|c|}{ 3 months } & 6 months & \multicolumn{1}{|c|}{ Year round } \\
\hline Total cost & $\mathbf{\$ 1 , 2 5 1 , 1 4 7}$ & $\mathbf{\$ 9 6 2 , 9 2 2}$ & $\mathbf{\$ 7 5 8 , 0 2 2}$ \\
\hline Cost/liter & $\$ 0.06$ & $\$ 0.05$ & $\$ 0.04$ \\
\hline Cost/MT & $\$ 24.82$ & $\$ 19.10$ & $\$ 15.05$ \\
\hline Cost/hectare & $\$ 389.54$ & $\$ 299.79$ & $\$ 236.01$ \\
\hline
\end{tabular}


Table 8 . The estimated profit margin for custom harvesting and hauling operations

\begin{tabular}{|c|c|c|c|}
\hline \multirow[t]{2}{*}{ Category } & \multicolumn{3}{|c|}{ Harvesting Schedule } \\
\hline & 3 months & 6 months & Year round \\
\hline \multicolumn{4}{|c|}{ Harvesting (\$/ton) } \\
\hline Custom rates & $\$ 33.47$ & $\$ 33.47$ & $\$ 33.47$ \\
\hline Total cost & $\$ 15.62$ & $\$ 12.08$ & $\$ 10.61$ \\
\hline Profit margin & $\$ 17.85$ & $\$ 21.39$ & $\$ 22.86$ \\
\hline \multicolumn{4}{|c|}{ Hauling (\$/ton) } \\
\hline Custom rates & $\$ 10.06$ & $\$ 10.06$ & $\$ 10.06$ \\
\hline Total cost & $\$ 5.02$ & $\$ 4.18$ & $\$ 3.84$ \\
\hline Profit margin & $\$ 5.04$ & $\$ 5.88$ & $\$ 6.22$ \\
\hline Total profit & $\$ 22.89$ & $\$ 27.27$ & $\$ 29.08$ \\
\hline
\end{tabular}




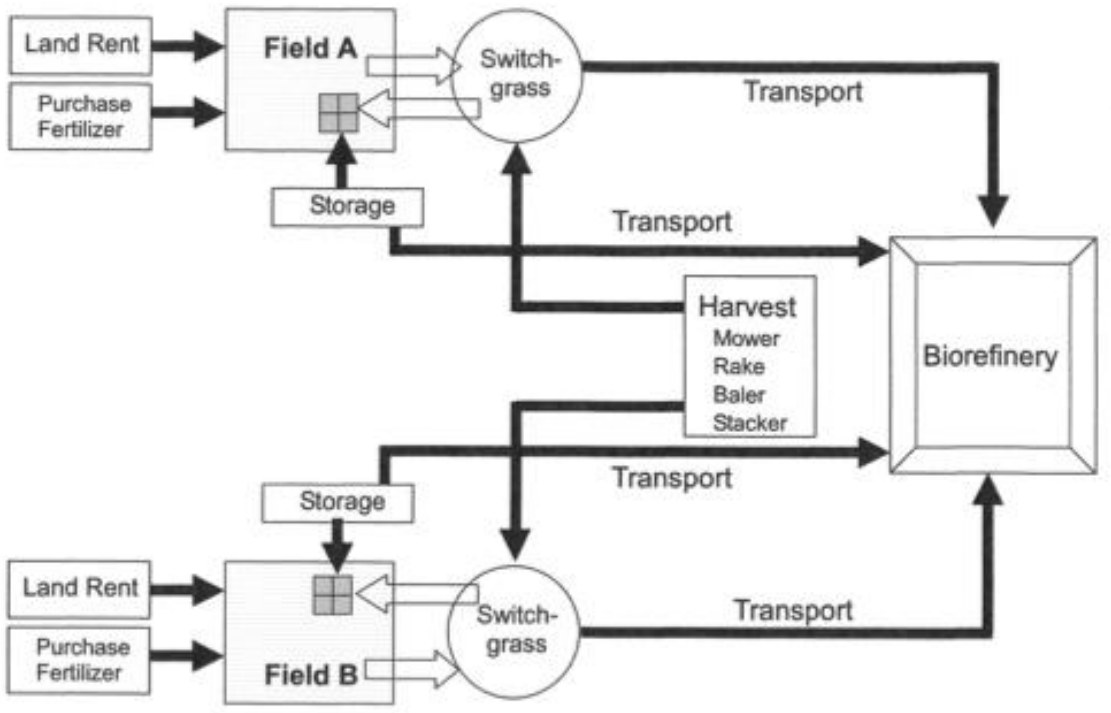

Figure 1: Flow of Switchgrass Feedstock from Fields to a Biorefinery (adopted from Hwang, 2007)
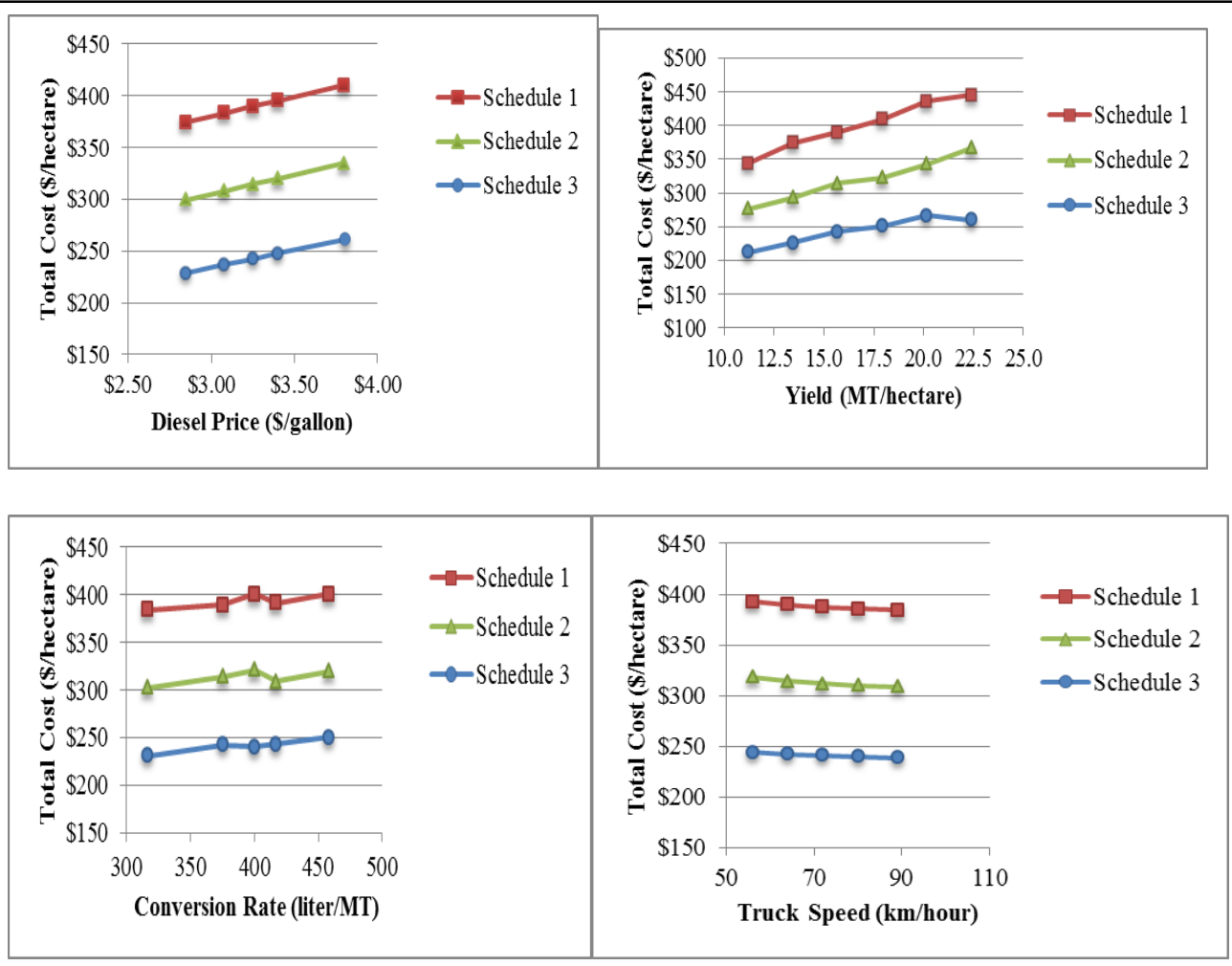

Figure 2. Sensitivity of key variables to total cost

Note: Schedule 1 refers to 3 months harvesting schedule; schedule 2 refers to 6 months harvesting schedule; and schedule 3 refers to 12 months harvesting schedule. 